\title{
INFLUENCE OF RELIEF AND LAND COVER ON THE DISTRIBUTION OF VALUES OF THE LAND SURFACE TEMPERATURE IN UPPER PARSĘTA RIVER AREA
}

\author{
Marta Kubiak, Alfred Stach \\ Institute of Geoecology and Geoinformation, Adam Mickiewicz University in Poznań, Poland
}

Manuscript received: November 23, 2012

Revised version: July 5, 2013

\begin{abstract}
KubiaK M., StACH A., 2013. Influence of relief and land cover on the distribution of values of the land surface temperature in upper Parsęta river area. Quaestiones Geographicae 32(3), Bogucki Wydawnictwo Naukowe, Poznań, pp. 39-51. 10 tables, 12 figs. DOI 10.2478/quageo-2013-0022, ISSN 0137-477X.

ABSTRACT. The primary research problem presented in the article is verification of the thesis on the influence of relief and land cover type on the spatial variability of the land surface temperature (LST) distribution in the area including the river catchment area of upper Parsęta. The paper presents the use of thermal channels from two Landsat ETM+ scenes pictures, Corine Land Cover database from 2000 as well as the DTED-2 digital elevation model. Two ETM+ thermal bands processing algorithms were used for calculation of the land surface temperature: Qin et al. (2001) and Jiménez-Muňoz et al. (2003). Conducted statistical tests show significant differences of the land surface temperature values between particular land cover forms as well as types of relief. LST maps can be applied in topoclimatology eg. to detail and verify the in situ measurements.
\end{abstract}

KEY WORDS: Land surface temperature (LST), topoclimate, remote sensing, Landsat, Polish Lowland

Address of the corresponding author: Alfred Stach, Institute of Geoecology and Geoinformation, Adam Mickiewicz University in Poznań, Dzięgielowa 27, 61-680 Poznań, Poland; e-mail: frdstach@amu.edu.pl

\section{Introduction}

In the last years, the aspect of thermal environment is of great interest as it is related to climate warming effect. This is related not only to air temperature, but also to land surface temperature (LST). Land surface temperature has direct influence on the air temperature and is one of the main physical parameters of processes occurring on the Earth's surface locally, regionally and globally. The thermal remote sensing (TRS) is used in environmental research to study: temperature distribution on continents surface, volcanic activity (use of MODIS thermal scan- ner), vegetation condition (Berni et al. 2009), soil moisture assessment (Hermanowska 1997), topoclimatic distribution (Kubiak 2009, Kubiak, Dzieszko 2012, Stach, Kubiak 2012, Wojkowski 2007), Earth's relief characteristics, bedrock mineral composition (Bakker 2004, Mularz 2005, Elachi, Zyl 2006), thermal anomaly occurring under the Earth's surface (Kuenzer, Hecker 2008), permafrost existence and character (Kędzia et al. 1998), geothermal gradient associated with geological structure (Maślankiewicz 1977), urban heat island presence and functioning ( $\mathrm{Xu}$ et al. 2001, Osińska-Skotak 2002, Voogt, Oke 2003, Amarsaikhan et al. 2005), waste disposal sites and 
places of wastewater flows (Ciolkosz et al. 1978, Torgersen et al. 2001, Kiev, Mania 2009).

As was mentioned above, TRS is used in topoclimatic studies because land surface temperature is one of the factors influencing the topoclimatic diversity. Therefore on the basis of its values it can be assumed that their application would be well-founded for developing topoclimatic maps. The advantage of thermal images is the fact that they show surface temperature diversity in a large area in a continuous manner with equal accuracy. Earlier published papers were based on standard microclimatic (ground) measurements (Komar 1999, Kolendowicz 2002).

The aim of the paper is specification of the influence of relief and land cover/use on the variation of the land surface temperature distribution in the area of upper Parsęta catchement. Due to low diversity of relief in lowland areas it is possible to hypothesise that the main factor influencing the diversity of land surface temperature is the land cover. Despite this fact, it was also decided to verify the thesis on the influence of relief on the distribution of values of the land surface temperature. It can be expected that the influence of relief shall be more significant in non-forest areas (with less dense and high vegetation) than in forested areas.

\section{Study area and source data}

The main area of research was the river basin of upper Parsęta. The river basin is located in the area of the Drawskie Lakeland mesoregion, in the range of marginal zone of the Pomeranian phase of north Poland glaciation. The river basin is comprised by the Natural Environment Monitoring program - scientific research has been conducted in its area for years, providing long measurement series of meteorological and hydrological parameters. The river basin of upper Parsęta due to its external structure is regarded as a representative for last glacial areas of the temperate climatic zone (Kostrzewski et al. 1994).

The use of land existing in the river basin area of upper Parsęta is a reflection of the distribution of sediments and soils as well as distribution of relief forms. A characteristic feature of the river basin is the mosaic layout of land use/land cover (LULC) related to the primary forms of last glacial relief. Due to the prevalence of arable lands and forests, which amount in total to $75 \%$, the river basin of upper Parsęta can be classified as an agricultural and forest type of landscape. Forest areas comprise 38\% of the entire river basin, arable lands cover $37 \%$ of the river basin's surface, grasslands (meadows and pastures) comprise $10 \%$ of the river basin's surface, while the remaining $15 \%$ of the surface of river basin of upper Parsęta is covered by built-up and communications areas (Piotrowska 1998). The characteristics of the LULC of the river basin of upper Parsęta was developed on the basis of topographic maps and area verification at the beginning of 1990's.

The above description of research regards the river basin of upper Parsęta, while geoinformation analyses were conducted in a rectangular area with the coordinates of $16^{\circ} 22^{\prime} \mathrm{E}$ and $53^{\circ} 48^{\prime} \mathrm{N}$ (NW boundary map point) as well as $16^{\circ} 38^{\prime} \mathrm{E}$ and $53^{\circ} 41^{\prime} \mathrm{N}$ (SE boundary map point). Upper Parsęta catchment area is $74 \mathrm{~km}^{2}$ while the area of presented analysis is $191.83 \mathrm{~km}^{2}$.

Analysis of the land cover and land use of the river basin of upper Parsęta was also conducted on the basis of the CLC2000 database (www.eea. europa.eu/themes/landuse) - Fig. 1. The area of Poland includes 31 forms of LULC in accordance with the terminology adopted in CLC2000. There are 12 such forms in the analysed area. According to the methodology of developing CLC databases, the minimum unit of allocated type amounts to 25 ha. All surfaces $<25$ ha are included into the adjacent surfaces. Geometric accuracy corresponds to the map in the scale of 1:100,000. Areas of particular CLC types for river basin area of upper Parsęta and for the area of analysis are presented in Table 1.

The problem with comparison of both characteristics of LULC (according to Piotrowska and CLC2000) arises from non-uniform terminology of the specified cover forms - some CLC2000 types are transitional forms of the primary forms of LULC described by Piotrowska (1998). Furthermore, differences can result from various accuracy and scale of source maps on which both studies were based. The differences are also influenced by the time differences of the used materials data of Piotrowska (1998) are from 1980's, while 


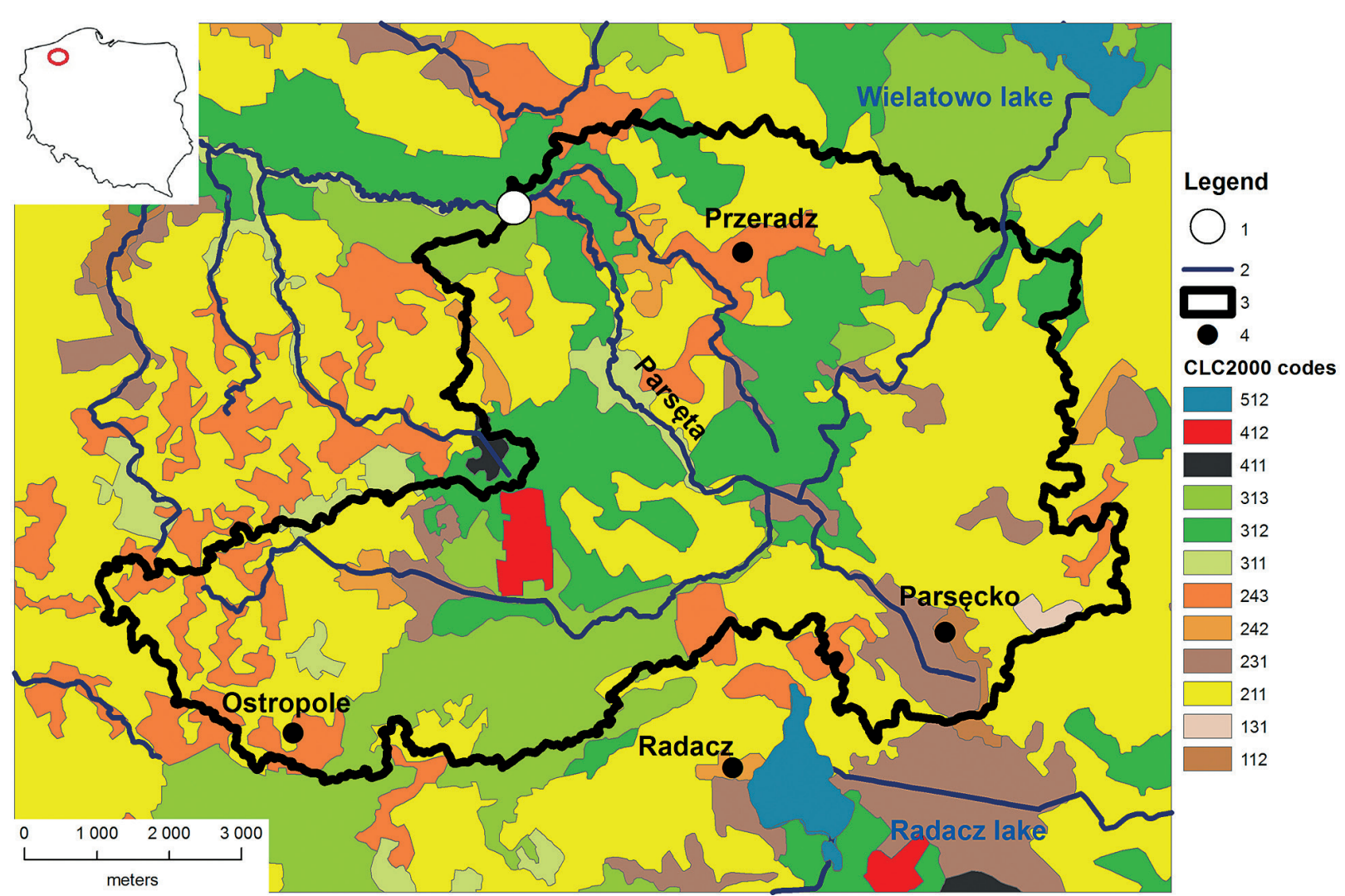

Fig. 1. Map of LULC in the area of analysis according to the CLC2000 classification

1 - Natural Environment Integrated Monitoring Station in Storkowo, 2 - main watercourses, 3 - watershed of the river basin of upper Parsęta, 4 - selected localities, CLC2000 codes: 112 - discontinuous urban fabric; 131 - mineral extraction sites; 211 - non-irrigated arable land; 231 - pastures; 242 - complex cultivation patterns; 243 - land principally occupied by agriculture, with significant areas of natural vegetation; 311 - broad-leaved forest; 312 - coniferous forest; 313 - mixed forest; 411 - inland marshes; 412 - peat bogs*; 512 - water bodies

*In the case of the river basin area of upper Parsęta, this category is comprised of an excavated hole related to utilisation of peat

the data of Corine Land Cover are from about 2000. It was assumed in overall that similarly as in the case of Piotrowska (1998), the prevailing percentage of land cover forms on the CLC2000 map are arable lands and forests. The percentage share of arable lands according to CLC2000 in relation to the value according to Piotrowska (1998) is higher and amounts to approx. 50\% (in relation to $37 \%$ ). Forests on the CLC2000 map comprise $36 \%$ (according to Piotrowska (1998) - 38\%, for the upper Parsęta catchment area).

The river basin of upper Parsęta is located in a last glacial area. Among the various system of glacial forms existing here, it is necessary to mention: hills of oscillating terminal moraines, plains of ground moraines, various types of crevice forms as well as local outwash plains and melt-out depressions. The Holocene relief is mainly comprised of sections of river valleys, erosive dissections, lake districts and small alluvial fans. The highest point in the river basin of upper Parsęta is Góra Polska Hill with the height of $202.84 \mathrm{~m}$ above mean sea level (Kostrzewski et al. 1994). The minimum height of the area of

Table 1. Areas of particular CLC2000 classes existing in the upper Parsęta river area and the area of analyses

\begin{tabular}{|c|r|r|r|r|}
\hline \multirow{2}{*}{} & \multicolumn{4}{|c|}{$\begin{array}{c}\text { Area } \\
\text { apper Parsęta river }\end{array}$} \\
\hline CLC class & {$\left[\mathbf{k m}^{2}\right]$} & \multicolumn{1}{c|}{$[\%]$} & \multicolumn{1}{c|}{ Area of analysis } \\
\hline 112 & 0.38 & 0.51 & 1.16 & 0.60 \\
\hline 131 & 0.28 & 0.38 & 0.28 & 0.15 \\
\hline 211 & 32.81 & 44.19 & 89.82 & 46.82 \\
\hline 231 & 4.85 & 6.54 & 13.37 & 6.97 \\
\hline 242 & 1.35 & 1.81 & 2.23 & 1.16 \\
\hline 243 & 6.56 & 8.83 & 18.76 & 9.78 \\
\hline 311 & 1.44 & 1.95 & 5.26 & 2.74 \\
\hline 312 & 14.93 & 20.08 & 30.50 & 15.90 \\
\hline 313 & 10.47 & 14.11 & 26.06 & 13.59 \\
\hline 411 & 0.02 & 0.38 & 0.50 & 0.26 \\
\hline 412 & 0.91 & 1.21 & 1.34 & 0.70 \\
\hline 512 & 0.00 & 0.00 & 2.55 & 1.33 \\
\hline total: & 74.00 & 100.00 & 191.83 & 100.00 \\
\hline
\end{tabular}




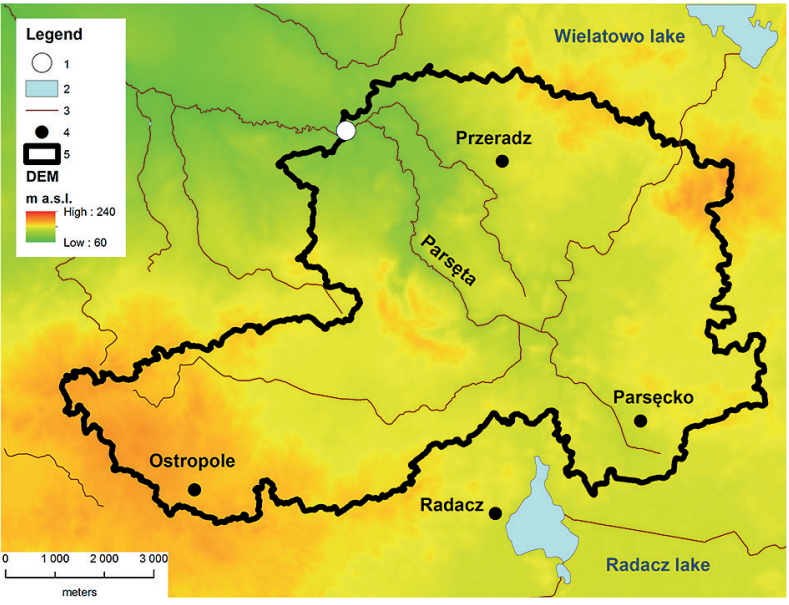

Fig. 2. DTED-2 numerical area model of the analysed area 1 - Natural Environment Integrated Monitoring Station in Storkowo, 2 - main water bodies 3 - main watercourses, 4 - selected localities, 5 - watershed of the river basin of upper Parsęta

analysis approx. amounts to $70 \mathrm{~m}$ above mean sea level, whereas the average height of the analysed area amounts to $142 \mathrm{~m}$ a.s.l. on the basis of the DTED-2 (Digital Terrain Elevation Data Level 2) (Fig. 2). Majority of Poland's area (except for the most southern areas) is located in the second zone between $50-70^{\circ} \mathrm{N}$, for which the information resolution amounts to 1 per 2 arc seconds (Gotlib et al. 2006). Original DTED-2 data in the WGS-84 system with a horizontal resolution corresponding in the field to 1 per 2 arc seconds (i.e. $x \approx 36 \mathrm{~m}, \mathrm{y} \approx 31 \mathrm{~m}$ ) and vertical resolution amounting to $1 \mathrm{~m}$ (horizontal accuracy $=16 \mathrm{~m}$, vertical accuracy $=2-7 \mathrm{~m}$ ) was converted to a uniform grid square in the PUWG 1992 (Polish Coordinate System) coordinate system and grid mesh of $35 \times 35 \mathrm{~m}$. The developed DEM (Digital Elevation Model) served to prepare a map of aspect (Fig. 11) and slope (Fig. 12).

The paper presents the use of two satellite scenes taken by the Landsat 7 satellite on 13 June and 24 September 2000. The images have been registered at 10.0 UTC of the Universal Time Clock (UTC) under cloudless sky condition.

\section{Methodolgy}

The value of land surface temperature (LST) was calculated on the basis of channels six of the Landsat ETM+ satellite images (spatial resolution of channels of visible light and near infrared: approximately 30 metres, thermal chan- nel: 60 metres per pixel) with the use of the LST software (Zhang et al. 2006). They described the methodology of obtaining the values of land surface temperature directly from channel six of the TM/ETM+ sensor on the basis of the algorithm of Qin et al. (2001) as well as algorithm of Jiménez-Muňoz et al. (2003). Software R, 2.9.2 version with R-Commender GUI module (Venables et al. 2012) and STATISTICA 8 (StatSoft 2006) statistical software were used for the LST data analysis.

Each object emits electromagnetic radiation, including in the thermal scope (channel 6 of the Landsat EMT+ satellite's thermal infrared includes waves of a length of $10.40-12.50 \mu \mathrm{m}$ ) if its temperature exceeds the absolute zero $\left({ }^{\circ} \mathrm{K}\right)$. The satellite's sensor registers the brightness temperature, which must be converted to kinetic temperature. In order to obtain reliable LST values, four steps of the correction process are required:

- conversion of reflected spectral radiation reaching the sensor to temperature,

- correction of the atmospheric absorption and re-emission;

- correction of the surface emission as well as

- correction of surface roughness.

In order to facilitate calculations, the abovementioned algorithms were developed: Qin et al. (2001) and Jiménez-Muňoz et al. (2003). In order to calculate the LST in the LST software (Zhang et al. 2006) with the use of the algorithm of Qin et al. (2001), it is necessary to provide three parameters: $T_{a}$ (average actual temperature of the atmosphere), $\varepsilon$ (soil emissiveness) as well as $\tau_{6}$ (atmospheric transparency). On the other hand, the algorithm of Jiménez-Muňoz and Sobrino (2003) requires providing two values: the value of soil emissiveness $\varepsilon$ (as in the case of the algorithm of Qin et al. 2001) as well as the total water vapour content in the atmosphere $w$.

\section{Maps of spatial variability of calculated land surface temperatures}

It was stated that generated maps based on the algorithms available in the LST program (Qin et al. 2001, Jiménez-Muňoz et al. 2003) show the approximate distribution of values of the surface temperature, only the absolute values differ slightly and this is not a constant difference 


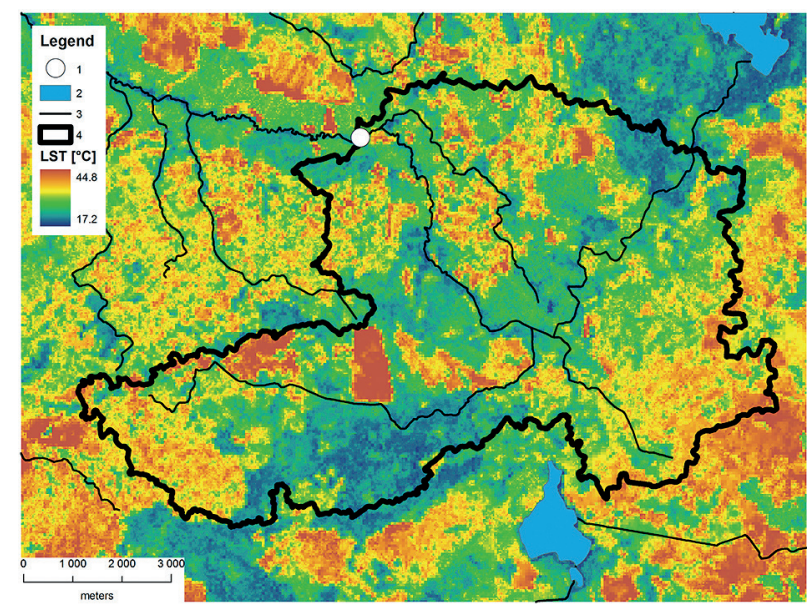

Fig. 3. Distribution of land surface temperature according to the algorithm of Qin et al. (2001) calculated for the analysed area at 10:00 am on 13 June 2000

1 - Natural Environment Integrated Monitoring Station in Storkowo, 2 - main water bodies, 3 - main watercourses, 4 - watershed of the river basin of upper Parsęta

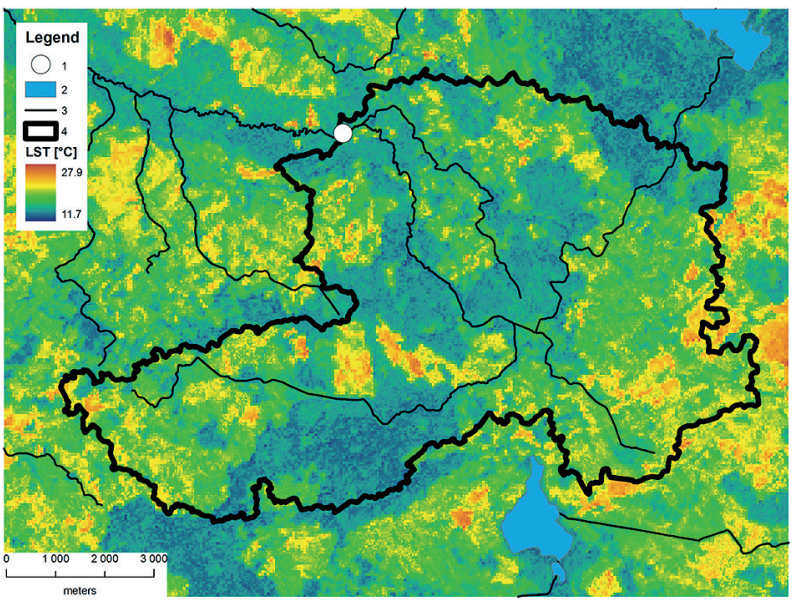

Fig. 4. Distribution of land surface temperature according to the algorithm of Qin et al. (2001) calculated for the analysed area at 10:00 am on 24 September 2000

1 - Natural Environment Integrated Monitoring Station in Storkowo, 2 - main water bodies, 3 - main watercourses, 4 - watershed of the river basin of upper Parsęta

- maximum in the hottest areas and minimum in the coldest areas (Kubiak 2009). On 13 June 2000, the difference between average, minimum and maximum LST values calculated with the method of Jiménez-Muňoz et al. (2003) and Qin et al. (2001) respectively amounted to: $4.6^{\circ} \mathrm{C}, 3.3^{\circ} \mathrm{C}$ and $6.8^{\circ} \mathrm{C}$. On 24 September 2000 , the differences between average, minimum and maximum value for algorithms of Jiménez-Muňoz et al. (2003) and Qin et al. (2001) respectively amounted to: -0.1 , -0.1 and 0.1 . Figures 3 and 4 show the maps of distribution of land surface temperature according to the algorithm of Qin et al. (2001).

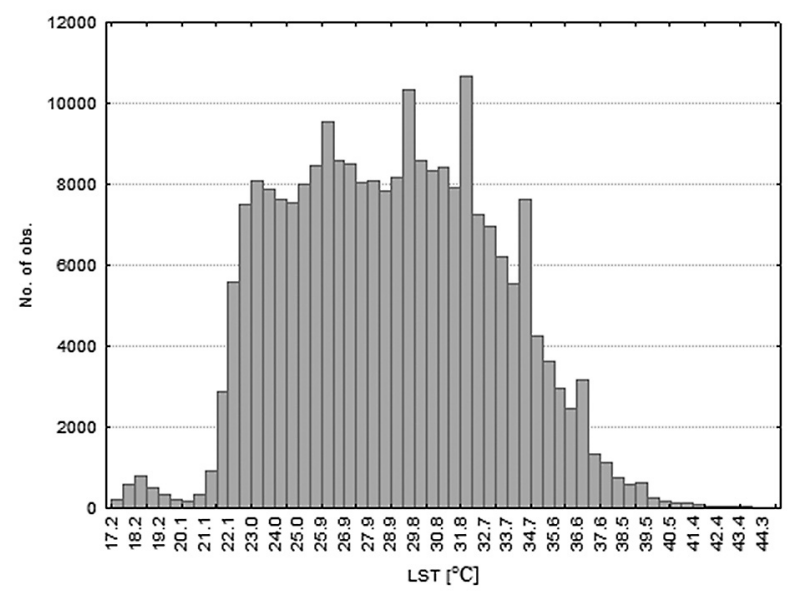

Fig. 5. Histogram of the value of land surface temperatures for the study area, according to the algorithm of Qin et al. (2001) based on the Landsat ETM+ imagery from at 10:00 am UTC on 13 June 2000

$\mathrm{N}=$ 236181; Mean = 28.9; Std. Dev. $=4.3 ; \operatorname{Max}=44.8 ; \operatorname{Min}=17.2$

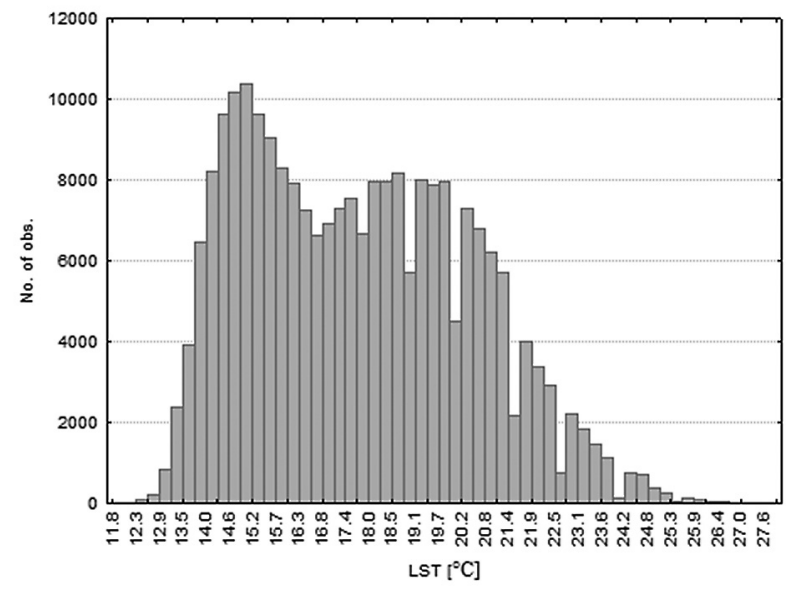

Fig. 6. Histogram of the value of land surface temperatures for the area of analysis according to the algorithm of Qin et al. (2001) based on the Landsat ETM+ imagery from at 10:00 am UTC on 24 September 2000

$\mathrm{N}=$ 236181; Mean = 17.7; Std. Dev. = 2.7; $\operatorname{Max}=27.9 ;$ Min = 11.8

Histograms of the value of land surface temperature were developed for both dates (Fig. 5 and 6). The biggest area expressed by the highest frequency in the histogram of 13 June 2000 (Fig. 5) is included in pixels with LST values in the range from 22.6 to $24.5^{\circ} \mathrm{C}$ (forests) as well as in the ranges from 25.0 to $26.9^{\circ} \mathrm{C}$ and from 28.9 to $31.8^{\circ} \mathrm{C}$ (arable lands). The smallest surface included pixels with the lowest temperature values: from 17.2 to $21.2^{\circ} \mathrm{C}$ (water bodies) and of the highest land surface temperature values: over $38^{\circ} \mathrm{C}$ (open pit after peat exploitation in the river basin area of upper Parsęta, which corresponds to the 412 CLC2000 category - peat bogs). With- 


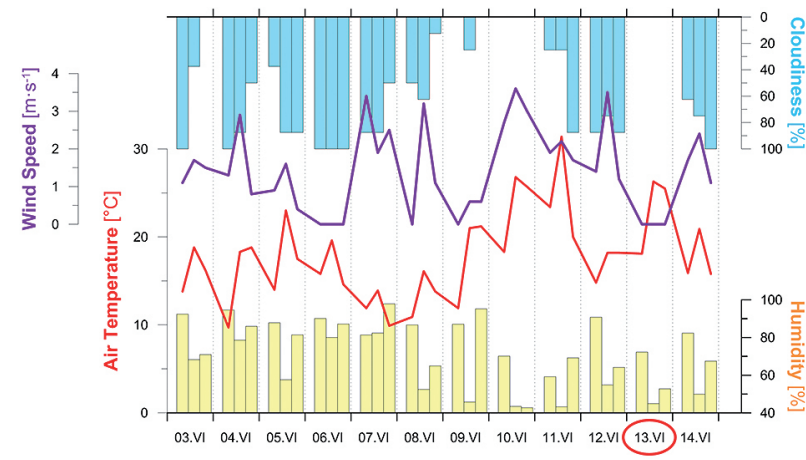

Fig. 7. Chart of values of temperature, air humidity, clouds as well as wind speed on 3 June - 14 June 2000, Storkowo

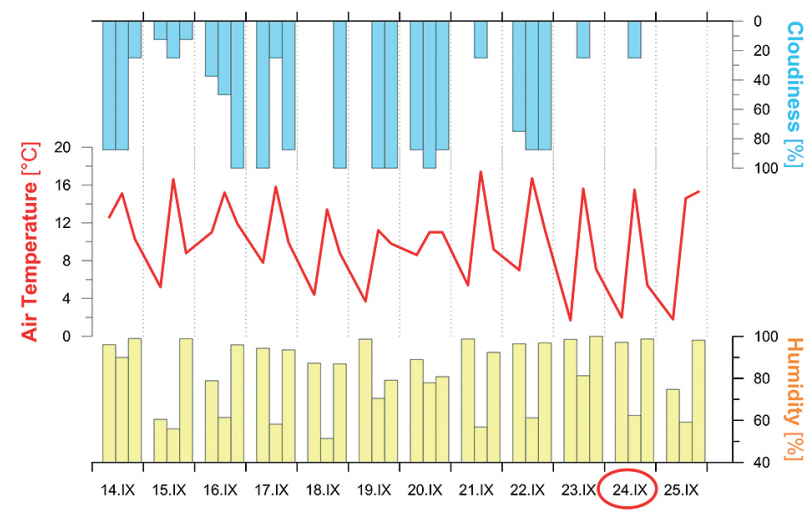

Fig. 8. Chart of values of temperature, air humidity, clouds as well as wind speed on 14 September -25 September 2000, Storkowo

in the range of 32.7 to $38^{\circ} \mathrm{C}$ we can observe a declining frequency of observations (pixels) with exception of columns with a higher number of observations with a temperature of approx. 34.7 and $37.1^{\circ} \mathrm{C}$ - these are the urban areas.

The biggest are in the above histogram (Fig. 6) includes pixels with LST values in the range from 14.3 to $16.3^{\circ} \mathrm{C}$ (forests) and from 17.4 to $20.5^{\circ} \mathrm{C}$ (arable lands). Similarly as in the histogram of 13 June 2000, waters are clearly distinguished (relatively small surface, low temperatures) as well as small areas with very high LST values (excavation pits, urban areas).

The radiation intensity in sunshine days is directly proportional to the sun's altitude above the horizon. On 24 September 2000 at 10:00 am UTC the sun's altitude amounted to $35^{\circ}$ (on this day, the sunrise occurred at 4:44 am UTC, it reached its zenith at 10:46 am UTC at an angle of $36^{\circ}$ ), whereas on 13 June 2000, the sun's altitude amounted to $58^{\circ}$ (sunrise occurred at 2:23 am UTC and it reached its zenith at 10:54 am UTC at the altitude of $\left.59^{\circ}\right)$. Among others, this was the reason for which land surface temperature values in June were relatively higher in comparison to September. Figures 7 and 8 show the weather conditions (temperature and air humidity, clouds) at the day of taking the picture, ten days prior to the day of taking the picture as well as the day after taking the picture (13 June 2000 and 24 September 2000). Meteorological data come from the Geoecological Station in Storkowo from standard measurements hours: 7, 13 and 19:00 UTC.

At the beginning of June 2000 (1 June to 11 June), the circulation in Central Europe was related to high pressure ridge (BM) in this area. In the next days (12 June-16 June), the circulation changed to west anticyclone (WA). In days prior to 24 September 2000, the synoptic situation of Central Europe was related to the anticyclone from Fennoscandia (HFA), which maintained up to 27 September 2000 (Gerstengarbe, Werner 2005).

The day of 13 June 2000 was characterised by a relatively high average air temperature $\left(23.3^{\circ} \mathrm{C}\right)$ in comparison to the average for eleven day period (3 June-13 June 2000) temperature amounting to $18.1^{\circ} \mathrm{C}$. The day of 24 September 2000 , in comparison to ten days prior, was characterised by a relatively low average air temperature of $7.6^{\circ} \mathrm{C}$ (average temperature of 11 days, 14 September-24 September 2000 amounts to $10.2^{\circ} \mathrm{C}$ ). Air humidity on 13 June 2000 in Storkowo amounted to $61 \%$ (average for days between 3 June and 13 June 2000 was equal to $72 \%$ ), whereas on 24 September 2000 it amounted to $89 \%$ with an average on 14 September to 24 September 2000 equal to $85 \%$. Both values did not deviate significantly from the 11-day average. The day of 13 June 2000 was cloudless. On 12 June 2000, the sky was covered with clouds in $81 \%$ - this could result in decrease of the land surface temperature values at the day of taking the satellite picture $(10: 00 \mathrm{am})$, that is on 13 June 2000. On 24 September 2000, the sky was covered in clouds in $13 \%$. During the week prior to the day of taking the picture, a significantly cloud-covered sky was recorded twice (20 October 2000 - 94\%, 22 October $2000-81 \%$ ), which could have an impact on the level of heating of the land's surface. 


\section{Results}

\subsection{LST and the land use/land cover (LULC) forms}

The first stage of works was testing of the significance of LST differences within LULC classes with the use of a variance analysis (Table 1 and 2). The low value of testing probability $(p)$ indi- cates to a significant dependency of the tested dependable variables (LST of 13 June 2000 and 24 September 2000) from the independent variable (CLC 2000 LULC classes) - Table 2 and 3. The F statistic informs about the significance of impact of the factor (independent variable) on the tested feature (dependent variable). On 24 September 2000, the impact of LULC was greater than on 13 June 2000.

Table 3. Single-factor analysis of the variance for the LST image (according to the algorithm of Qin et al. 2001) of 24 September 2000 within CLC2000 LULC classes

\begin{tabular}{|l|r|r|r|r|c|}
\hline \multicolumn{1}{|c|}{ Effect } & SS & df & MS & F & p \\
\hline Intercept & 6435674 & 1 & 6435674 & 1803852 & 0.00000 \\
\hline CLC & 880571 & 11 & 80052 & 22438 & 0.00000 \\
\hline Error & 842589 & 236169 & 4 & & \\
\hline
\end{tabular}

Symbols - see explanation under Table 2

Table 2. Single-factor analysis of the variance for the LST image (according to the algorithm of Qin et al. 2001) of 13 June 2000 within CLC2000 LULC classes

\begin{tabular}{|l|c|r|r|r|c|}
\hline \multicolumn{1}{|c|}{ Effect } & SS & df & MS & F & p \\
\hline Intercept & 17378758 & 1 & 17378758 & 1747025 & 0.00000 \\
\hline CLC & 2050704 & 11 & 186428 & 18741 & 0.00000 \\
\hline Error & 2349321 & 236169 & 10 & & \\
\hline
\end{tabular}

SS stands for Sum of Squares - it is the sum of the squares of the deviations from the means, $d f$ stands for degrees of freedom - the number of values in the final calculation that are free to vary, MS stands for Mean Square and is found by dividing the variation by the degrees of freedom (for detailed information see STATISTICA Electronic Manual website)

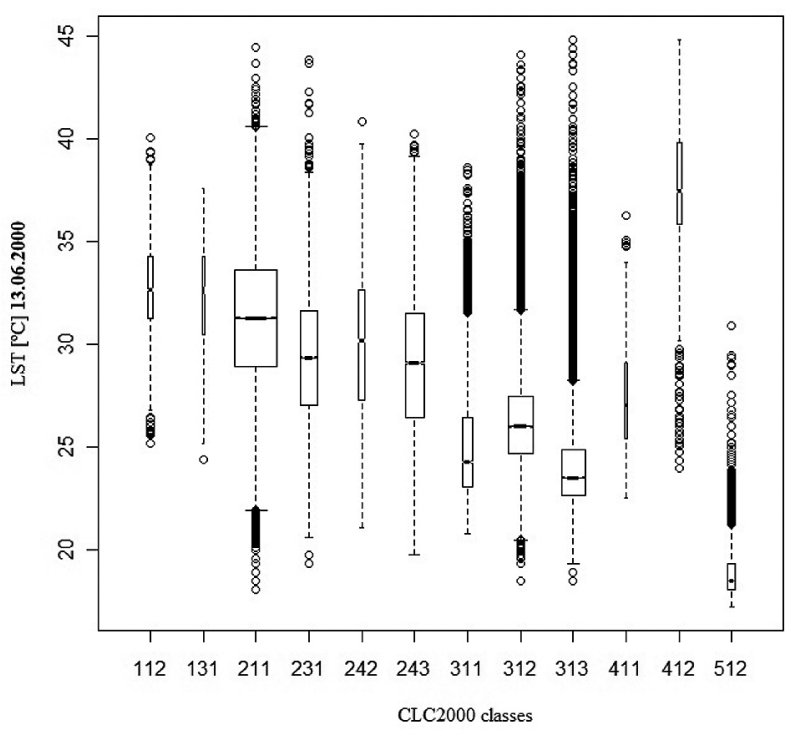

Fig. 9. Box plot chart of the LST values $\left[{ }^{\circ} \mathrm{C}\right]$ specified on the basis of the algorithm of Qin et al. (2001) for CLC2000 LULC classes on 13.06.2000 at 10:00 am UTC

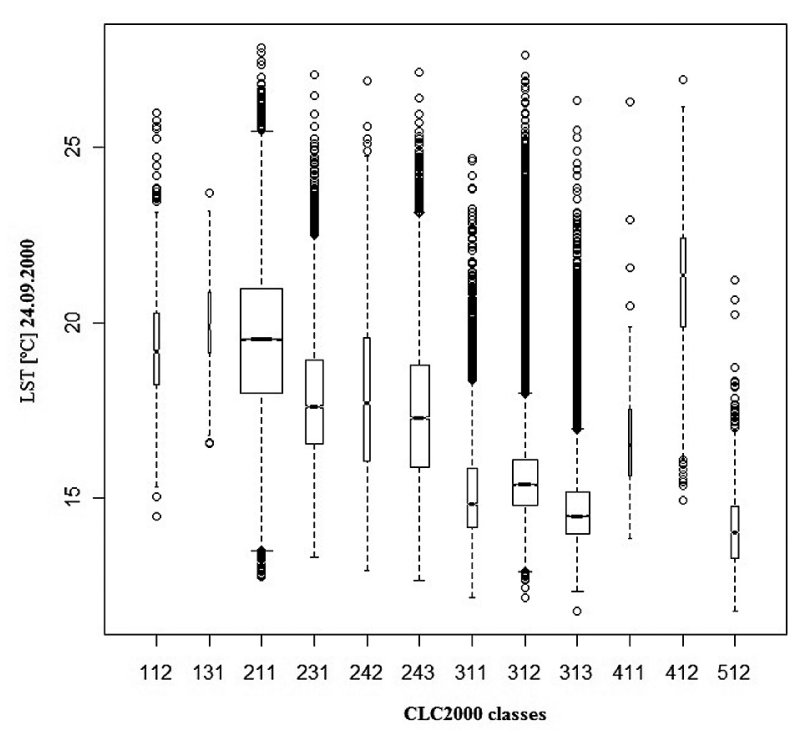

Fig. 10. Box plot chart of the LST values $\left[{ }^{\circ} \mathrm{C}\right]$ specified on the basis of the algorithm of Qin et al. (2001) for CLC2000 LULC classes on 24.09.2000 at 10.00 am UTC

112 - discontinuous urban fabric, 131 - mineral extraction sites , 211 - non-irrigated arable land, 231 - pastures, 242 - complex cultivation, 243 - land principally occupied by agriculture, with significant areas of natural vegetation, 311 - broad-leaved forest, 312 - coniferous forest, 313 - mixed forest, 331 - beaches, dunes, and sand plains, 411 - inland marshes, 412 - peatbogs, 512 - water bodies 


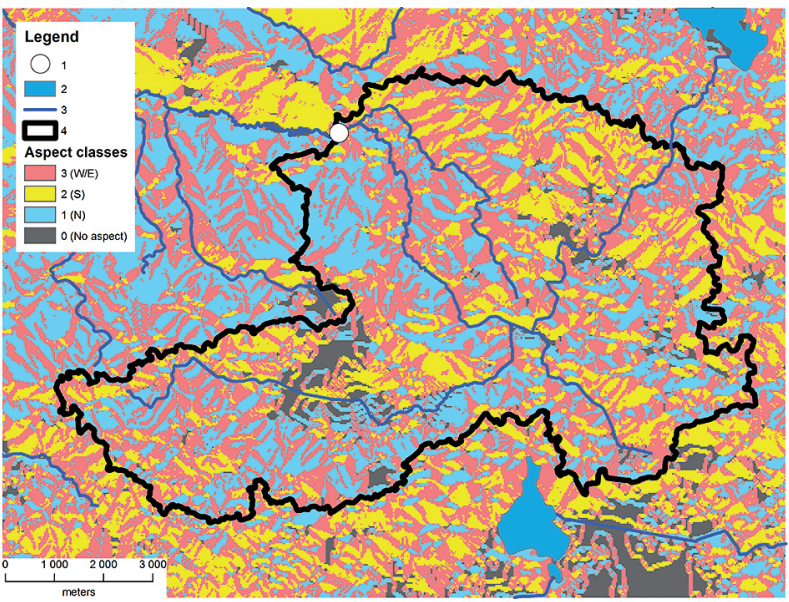

Fig. 11. Slope aspect in the analysed area

1 - Natural Environment Integrated Monitoring Station in Storkowo, 2 - main water bodies 3 - main watercourses, 4 - watershed of the river basin of upper Parsęta

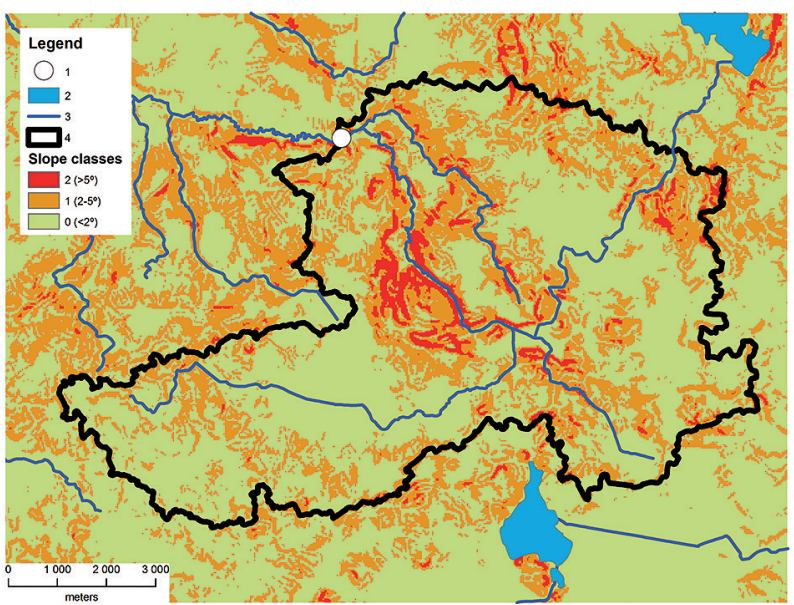

Fig. 12. Slope classes in the analysed area 1 - Natural Environment Integrated Monitoring Station in Storkowo, 2 - main water bodies 3 - main watercourses, 4 - watershed of the river basin of upper Parsęta

One of the criteria of use of the variance analysis is the equality of variances in particular groups. In the case of thermal images, this condition was not maintained. However, due to the big size of particular groups, breach of this condition does not influence the result of the variance analysis. The Kruskal-Wallis's non-parametric test was conducted in order to verify this thesis. The test shown the same results as the ANOVA test, therefore, despite that the analysed case reported lack of homogeneousness of the variance (Levene's test), it was decided to use the results of the variance analysis.

Box plot charts (Figs 9 and 10) show the thermal characteristics for particular forms of LULC. The number of outlier values (black circles) and their amplitude indicates the heterogeneousness of the given class. The box width presents the number of samples (pixels) in category, whereas the box notches width signifies $95 \%$ median confidence interwval. The charts show that classes 412 (in this case the excavation hole from peat utilisation) and 512 (water bodies) vary the most from other classes. It is necessary to stress at this point that due to the relatively low spatial resolution of source data, the obtained results are somewhat general and simplified in comparison to actual situation.

Due to the use of "post hoc" tests of multiple comparisons we are able to indicate the LULC classes which do not differ significantly. The used statistical tests analyse only the significance of differences of average values. The difference may result not only from the averages - it is an important, however not the only aspect of statistical analyses. Among tests available in the STATISTICA program, it was decided to chose the Scheffe's test for the analysis. The test is considered as the most conservative. The test's conservativeness informs about the ability to detect significant differences. Increase in the conservativeness means the increase in certainty that the detected differences actually exist in population (Stanisz 2007). The Scheffe's test of multiple comparisons for the scene of 13 June 2000 has shown that almost all LULC classes differ significantly in terms of the LST value. Only classes 112 (discontinuous urban fabric) and 131 (mineral extraction sites) are similar in terms of the thermal characteristics. The Scheffe's test of multiple comparisons for the picture of 24 September 2000 has shown that class 211 (non-irrigated arable land) does not differ significantly in terms of the thermal characteristics from classes: 112 (discontinuous urban fabric) and 131 (mineral extraction sites) as well as that classes: 231 (pastures) and 242 (complex cultivation patterns) are similar in terms of the thermal aspect. Other analysed LULC classes differ significantly.

\subsection{LST and the land relief}

Relief of the land surface has a huge impact on climatic processes in a local scale. The role of slope aspect partially resembles the impact of latitude on insolation. In the northern hemisphere, 
slopes of a northern aspect often receive less solar radiation than southern slopes. The thermal balance of slopes of various aspect - despite significant differences in the inflow of solar radiation - is supplemented to a certain degree by a stream of sensible heat, transferred for example by local air circulation. Nonetheless, the result of aspect impact is a noticeable increase in air temperature (and even larger increase of soil temperature) Table 4. Classes of LULC forms at slopes exceeding $2^{\circ}$

\begin{tabular}{|c|c|c|}
\hline Type & CLC2000 code & LULC classes \\
\hline grade: F (1) & $311,312,313$ & $\begin{array}{c}\text { forests (deciduous, } \\
\text { coniferous, mixed) }\end{array}$ \\
\hline grade: A (2) & 211 & $\begin{array}{c}\text { non-irrigated arable } \\
\text { land }\end{array}$ \\
\hline
\end{tabular}

on the slopes exposed to the sun (Kożuchowski 2006).

The primary aim of the paper was verification of the hypothesis that besides the land cover, which is the main factor influencing the diversity of LST values on last glacial areas, also land relief differentiates the distribution of surface temperature. In order to test this influence, two LULC forms were chosen from the CLC2000 - non-irrigated arable land (code 211) and forests (codes 311, 312 and 313). These areas cover the highest percentage of the river basin area of upper Parsęta, thus increasing the reliability of obtained results and interpretation of analyses (Table 1). Next, areas differing in slope and aspect were distinguished in

Table 5. Areas of different aspect classes in different slope conditions in the area of arable lands and forests

\begin{tabular}{|c|c|c|c|}
\hline \multirow{2}{*}{ Slope } & \multicolumn{3}{|c|}{ Aspect } \\
\hline & northern $\left(0-45^{\circ}\right.$ and $\left.315-360^{\circ}\right)$ & southern $\left(135-225^{\circ}\right)$ & western/eastern $\left(45-135^{\circ} / 225-315^{\circ}\right)$ \\
\hline$<2^{\circ}$ & $<2-\mathrm{N}(1)$ & $<2-\mathrm{S}(4)$ & $<2-\mathrm{W} / \mathrm{E}(7)$ \\
\hline from 2 to $5^{\circ}$ & $2-5-\mathrm{N}(2)$ & $2-5-S(5)$ & $2-5-W / E(8)$ \\
\hline$>5^{\circ}$ & $>5-\mathrm{N}(3)$ & $>5-S(6)$ & $>5-W / E(9)$ \\
\hline
\end{tabular}

Table 6. Surface area (in $\mathrm{km}^{2}$ ) of classes of slopes and aspect in the analysed area

\begin{tabular}{|c|c|c|c|}
\hline \multirow{2}{*}{ Slope } & \multicolumn{3}{|c|}{ Aspect } \\
\hline & northern $\left(0-45^{\circ}\right.$ and $\left.315-360^{\circ}\right)$ & southern $\left(135-225^{\circ}\right)$ & western/eastern $\left(45-135^{\circ} / 225-315^{\circ}\right)$ \\
\hline$<2^{\circ}$ & 34.1 & 29.9 & 53.9 \\
\hline from 2 to $5^{\circ}$ & 18.1 & 12.9 & 25.8 \\
\hline$>5^{\circ}$ & 1.9 & 1.1 & 3.0 \\
\hline
\end{tabular}

Table 7. Multi-factor variable analysis for the LST values (according to the algorithm of Qin and others 2001) of 13 June 2000 in the area of six classes of slope and aspect (Table 6) as well as two classes of LULC types (Table 5)

\begin{tabular}{|l|r|r|r|r|c|}
\hline \multicolumn{1}{|c|}{ Effect } & \multicolumn{1}{c|}{ SS } & df & MS & \multicolumn{1}{c|}{ F } & p \\
\hline Intercept & 35037781 & 1 & 35037781 & 3468220 & 0.00000 \\
\hline Relief & 33054 & 9 & 3673 & 364 & 0.00000 \\
\hline Landuse & 312769 & 1 & 312769 & 30960 & 0.00000 \\
\hline Relief*Landuse & 8485 & 9 & 943 & 93 & 0.00000 \\
\hline Error & 1885909 & 186677 & 10 & & \\
\hline
\end{tabular}

Symbols - see explanation under Table 2

Table 8. Multi-factor variable analysis for the LST values (according to the algorithm of Qin and others 2001) of 24 September 2000 in the area of six classes of slope and aspect (Table 6) as well as two grades of land cover/ use forms (Table 5)

\begin{tabular}{|l|r|r|r|r|c|}
\hline \multicolumn{1}{|c|}{ Effect } & \multicolumn{1}{c|}{ SS } & df & MS & F & p \\
\hline Intercept & 12880919 & 1 & 12880919 & 3755354 & 0.00000 \\
\hline Relief & 17366 & 9 & 1930 & 563 & 0.00000 \\
\hline Landuse & 154246 & 1 & 154246 & 44969 & 0.00000 \\
\hline Relief*Landuse & 7443 & 9 & 827 & 241 & 0.00000 \\
\hline Error & 640305 & 186677 & 10 & & \\
\hline
\end{tabular}

Symbols - see explanation under Table 2 


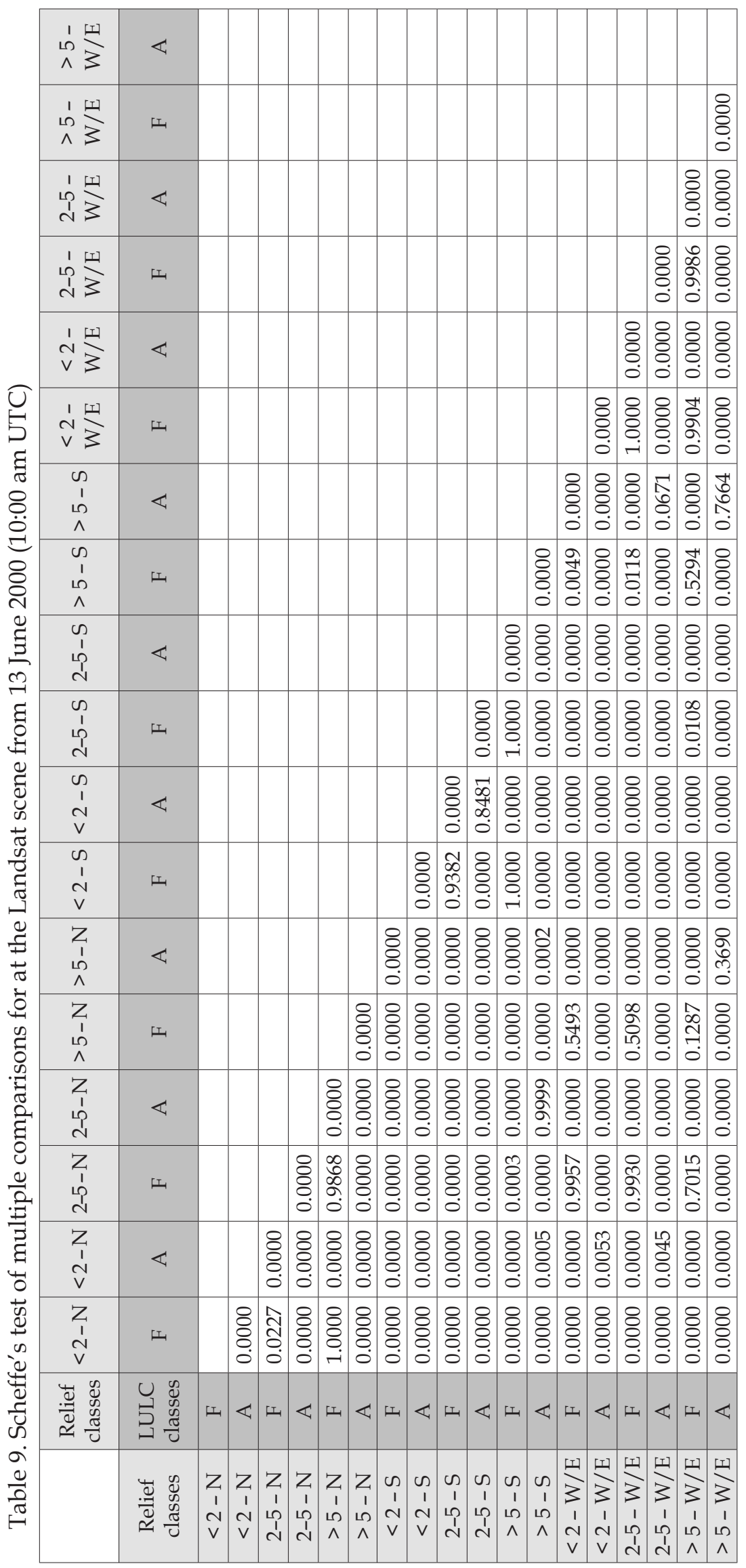




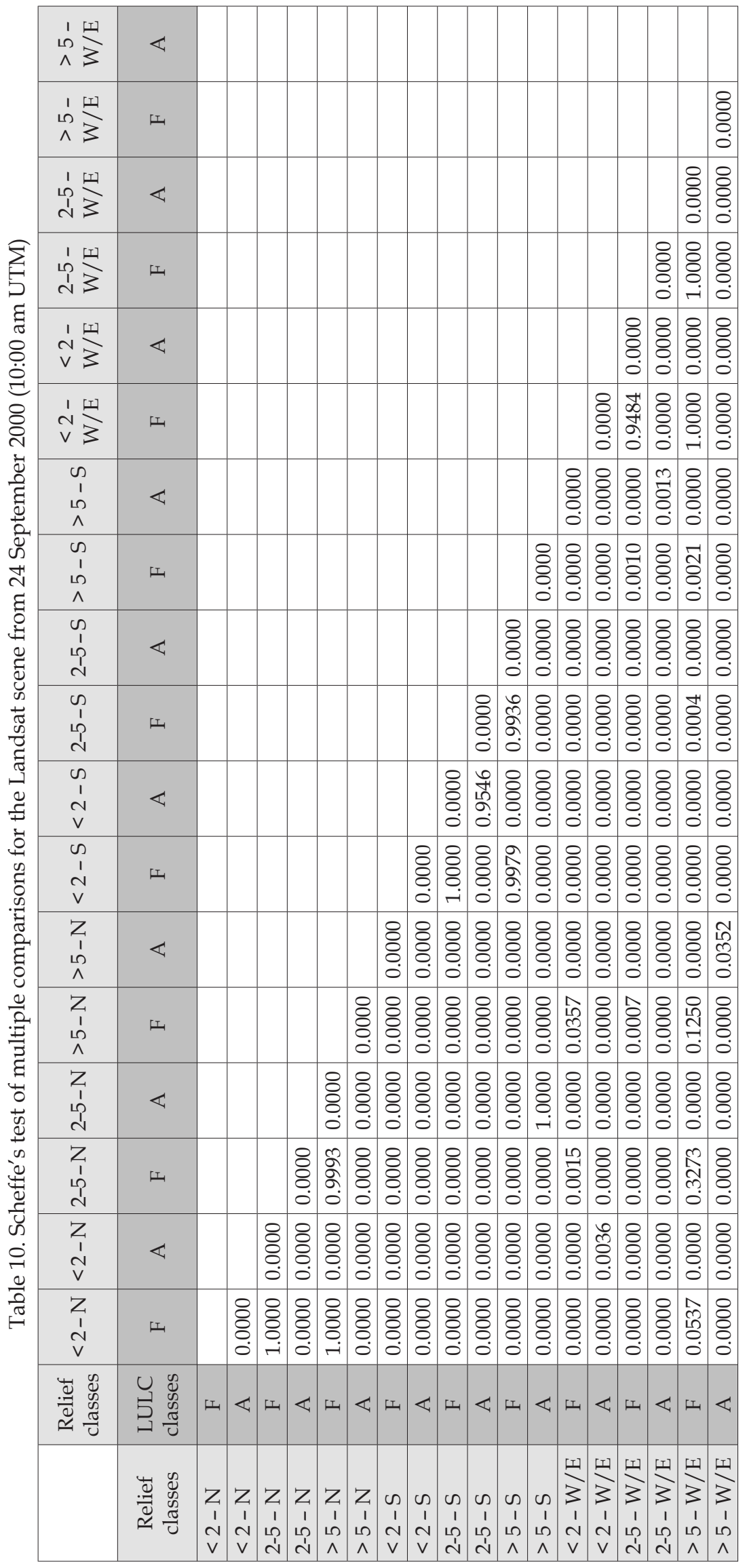


their range. The classes of terrain slope and aspect were adopted from the topoclimatic typology by Paszyński (1980). Since aspects were calculated in IDRISI Selva (Eastman 2012) software, their ranges were defined according to program settings as: northern $\left(0-45^{\circ}\right.$ and $\left.315-360^{\circ}\right)$, southern (135$\left.225^{\circ}\right)$ and western/eastern $\left(45-135^{\circ} / 225-315^{\circ}\right)$ aspects. Paszyński considered western and eastern aspects together. He has described flat areas without providing the ranges of slope values, in which they are classified. Therefore, it was decided to define them according to Klimaszewski (1978) as areas with a slope of up to $2^{\circ}$. The designated slopes are enlisted in tables (Table 4 and 5). Areas of particular classes of slopes and aspects (in $\mathrm{km}^{2}$ ) are enlisted in Table 6.

The variance analysis (Table 7 and 8 ) has shown the significance of differences in the LST in the area of designated classes of relief and LULC forms ( $p<0.05)$. In the case of both dates of taking thermal images, the LULC has significantly greater impact on LST values than land relief based on (F statistic). On 13 June 2000, the impact of LULC in relation to relief was greater in comparison to 24 September 2000.

The use of "post hoc" tests of multiple comparisons allows to indicate the groups which do not differ significantly. On the basis of the Scheffe's test of multiple comparisons for the image gathered on 13 June 2000 (Table 9) it was assumed that the land surface temperature at forested slopes with an identical aspect, however in various ranges of land slope does not differ significantly.

Forested areas existing at northern slopes with inclination from 2 to $5^{\circ}$ and above $5^{\circ}$ : $(2-5-\mathrm{N}-$ F), (> 5 - N - F) do not differ significantly and are characterised by similar LST values in relation to forested slopes with western/eastern aspects in all slope classes. Forested slopes with inclination exceeding $5^{\circ}$ and west/east aspect (> 5 - W/E F) are similar in terms of the thermal conditions to classes of the same slope, however different aspect: $(>5-\mathrm{N}-\mathrm{F})$ and $(>5-\mathrm{S}-\mathrm{F})$.

Areas of arable lands with slopes exceeding $5^{\circ}$ and west/east aspect (> 5 - W/E - A) are similar in terms of the thermal conditions (as in the case of forests) to classes with the same slope, however with different aspect: (> 5-N - A), (> 5-S A). Furthermore, areas with southern aspect and slopes from 2 to $5^{\circ}$ as well as below $2^{\circ}$ are characterised by a high similarity of LST values: $(<2-S$ $-\mathrm{A})$ and (2-5 - S - A). Slopes with southern exposure and inclination exceeding $5^{\circ}(>5-\mathrm{S}-\mathrm{A})$ do not differ thermally from slopes with inclination from 2 to $5^{\circ}$ and exposed to the north and west/ east: $(2-5-N-A)$ and $(2-5-W / E-A)$.

On the basis of the Scheffe's test of multiple comparisons for the image of 24 September 2000 (Table 10) it was assumed that as in the case of analysis for 13 June 2000, the land surface temperature at forested slopes with an identical aspect, however in various ranges of slopes, does not differ significantly. Forested slopes with west/east aspect and inclination exceeding $5^{\circ}(>5-\mathrm{W} / \mathrm{E}$ - F) do not differ significantly from slopes with northern aspect in all inclination classes: $(<2-\mathrm{N}$ - F), $(2-5-\mathrm{N}-\mathrm{F})$ and $(>5-\mathrm{N}-\mathrm{F})$.

Areas of arable lands with slopes exceeding $5^{\circ}$ and southern aspect are characterised by large similarity of the LST values (> 5 - S - A) with areas with slopes from 2 to $5^{\circ}$ and northern aspect (2-5 - N - A). Furthermore, areas with southern aspect, however different slope classes (as in the case of the analysis of 13 June 2000) are characterised by a high similarity of LST values: inclination below $2^{\circ}(<2-\mathrm{S}-\mathrm{A})$ and from 2 to $5^{\circ}$ (2-5 - S - A).

In general, it can be assumed that the LULC form influences the diversity of land surface temperature in the area of specified ranges of slopes and aspects. Forested area are characterised by smaller (less significant) differences in the LST values on slopes with various aspects and inclinations. Southern slopes of arable lands differ most significantly in terms of the land surface temperature value from other slopes, whereas western/eastern slopes are most similar in terms of the thermal aspect to slopes with other aspects.

Due to the relatively low spatial resolution of Landsat thermal images, the obtained results are somewhat general and simplified in comparison to real relations. The aim of the topoclimatic map is to show the representative information for long time, whereas the map based on thermal images only shows the temporary properties of the environment. Studies based on satellite data with high ground resolution shall always be limited in terms of temporal resolution. 


\section{Summary}

One of the main factors determining the topoclimatic variability is the land surface temperature. Analysis of its distribution in the river basin of upper Parsęta leads to the conclusions regarding the spatial topoclimatic variability in this area. The amount of solar energy reaching the land surface depends highly on the type of its cover, especially in lowland areas. The conducted statistical tests confirm this dependency. However, statistical analyses have also shown that the influence of inclinations and aspect of slopes can significantly modify the distribution of land surface temperature values.

Full topoclimatic analysis, also on last glacial lowland areas, requires taking into consideration both LULC forms and the influence of land relief. The conducted statistical tests showed significant differences in the land surface temperature values between particular LULC forms as well as land relief classes. On this basis, it can be assumed that development of topoclimatic maps based on LST (even with the use of relatively low accurate Corine Land Cover map and medium-resolution Landsat satellite images) is justified and can find an application in topoclimatology. In further analyses, it is planned to test the influence of circulation factors on LST values and optimise the slope and aspect ranges.

\section{References}

Corine Land Cover (CLC), 2000. Database. On-line: www.eea. europa.eu/themes/landuse (accessed 6 February 2012).

Dmowska A., 2007. Zróżnicowanie regionalnych charakterystyk morfometrycznych rzeźby w strefie pojezierzy potudniowobattyckich $i$ wschodniobattyckich. MS. Archiwum IGiG, Poznań.

Eastman J.R., 2012. IDRISI Selva. Worcester, MA, Clark University.
European Environment Agency, European Topic Center, Terrestrial Environment, 2002. Final version: CORINE Land Cover update IECLC2000 project Technical Guidelines. København.

Gerstengarbe F.W., Werner P.C., 1999. Katalog der Grosswetterlagen Europas nas Paul Hess und Helmuth Berezowski 1881-1998. Offenbach a. M., Potsdam

Gotlib D., Iwaniak A., Olszewski R., 2006. Budowa krajowej infrastruktury danych przestrzennych w Polsce - harmonizacja baz danych referencyjnych. Roczniki Geomatyki 5(1): 35-38.

Klimaszewski M., 1978. Geomorfologia. PWN, Warszawa.

Kolendowicz L., 2002. Zróżnicowanie temperatury, wilgotności względnej oraz wielkości ochładzającej powietrza w Słowińskim Parku Narodowym. Badania Fizjograficzne nad Polską Zachodnia, Geografia Fizyczna 53: 83-93.

Komar Z., 1999. Z badań nad zróżnicowaniem topoklimatycznym Parku Krajobrazowego „Dolina Słupi”. Badania Fizjograficzne nad Polska Zachodnia, Geografia Fizyczna 50: 91-115.

Kostrzewski A., 1998. Funkcjonowanie geosystemów zlewni rzecznych. Wydawnictwo Uczelniane Politechniki Koszalińskiej, Poznań.

Kostrzewski A., Mazurek M., Zwoliński Z., 1994. Dynamika transportu fluwialnego górnej Parsęty jako odbicie funkcjonowania systemu zlewni. Stowarzyszenie Geomorfologów Polskich, Poznań, 164 p.

Kożuchowski K., 2006. Meteorologia i klimatologia. Lokalne czynniki klimatu. Wydawnictwo Naukowe PWN, Warszawa: 232-244.

Kubiak M., 2009. Metodyka charakterystyki termalnej powierzchni ziemi w oparciu o dane teledetekcyjne. In: L. Kasprzak (ed.), Badania podstawowe i aplikacyjne w naukach geograficznych, Zakład Graficzny UAM, Poznań: 15-21.

Paszyński J., 1980. Metody sporządzania map topoklimatycznych. Dokumentacja Geograficzna 3: 13-28.

Qin Z., Karnieli A., Berliner P., 2001. A mono-window algorithm for retrieving land surface temperature from Landsat TM data and its application to the Israel-Egypt border region. Remote Sensing 22(18): 3719-3746.

Sobrino J.A., Jimenez-Munoz J.C., Paolini L., 2004. Land surface temperature retrieval from LANDSAT TM 5. Remote Sensing, Environment 90: 434-440.

Stanisz A., 2007. Przystępny kurs statystyki z zastosowaniem STATISTICA PL na przyktadach medycznych, Tom 2. Modele liniowe i nieliniowe. StatSoft Polska, Kraków.

StatSoft, 2012. STATISTICA Electronic Manual. On-line: documentation.statsoft.com/STATISTICAHelp.aspx?path=common/AboutSTATISTICA/ElectronicManualIndex (accessed 6 February 2012).

Zhang J., Wang Y., Li Y., 2006. A C++ program for retrieving land surface temperature from the data of Landsat TM/ ETM+ band6. Computers, Geosciences 32: 1796-1805. 